Boletín de la Sociedad Geológica Mexicana

VOLUMEN 67, NÚM. 1, 2015, P. 59-73

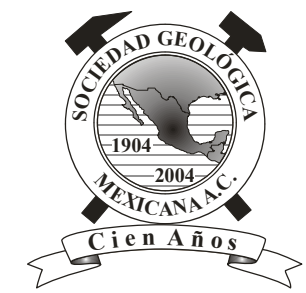

\title{
Foraminiferal paleoecology and paleoenvironmental reconstructions of the lower Miocene deposits of the Qom Formation in Northeastern Isfahan, Central Iran
}

\author{
Maryam Nouradini ${ }^{1, *}$, Seyed Hamidreza Azami², Mostafa Hamad ${ }^{3}$, Mehdi Yazdi ${ }^{4}$, \\ Ali Reza Ashouri ${ }^{1}$ \\ ${ }^{1}$ Department of Geology, Faculty of Science, Ferdowsi University of Mashhad, Mashad, POB. 9177948974, I.R. of Iran. \\ ${ }^{2}$ Department of Geodynamics and Sedimentology, Center for Earth Sciences, University of Vienna, Althanstrasse 14, A-1090 Vienna, \\ Austria. \\ ${ }^{3}$ Department of Geology, Faculty of Science, Cairo University, Cairo University Road Oula, Giza, Egypt. \\ ${ }^{4}$ Department of Geology, Faculty of Science, University of Isfahan, Isfahan, POB. 81746- 73441, I.R. of Iran.
}

*Maryam.nouradini@gmail.com

\begin{abstract}
The early Miocene Qom Formation is exposed in the Bagh section, northeast Isfahan, Central Iran, where it unconformably overlies Oligocene deposits and is unconformably overlain by the Upper Red Formation. The formation is mainly represented by carbonate deposits (marl, marly limestone facies) and subordinate siliciclastic facies. The planktonic foraminiferal biostratigraphical analysis led to recognition of two main planktonic foraminiferal zones: 1. the Globigerinoides primordius Zone in the lowermost part of the section indicating early Miocene (Aquitanian) and 2. the Globigerinoides trilobus Zone in the upper most part of the Qom Formation of Burdigalian age (early Miocene). Composition and abundance of benthic and planktonic foraminifers were examined for paleoenvironment reconstruction and paleoecology. The Q-mode cluster analysis performed on the benthic foraminifers led us subdivide the section into three distinct benthic foraminiferal clusters: I. the Cibicidoides ungerianus cluster in the lower part of succession, indicating predominantly inner neritic environments; II. the Lenticulina orbicularis cluster in the middle part of section, indicative of middle-outer neritic environments, and III. the Elphidium-Amphistegina cluster recorded in the upper part of the formation and characterizing a typical outer neritic environment. The planktonic foraminifers are interspersed in the upper part of the section with relatively low diversity, indicating open marine shelf segments, whereas the lower part of the section is characterized by an abundance of benthic foraminifers. As a point to consider for paleoecology and paleoenvironment, abundant although with low diversity benthic foraminifera with small tests, and calculated data based on these clusters are indicative of high nutrient and high oxygen environment with normal marine salinity during the early Miocene at the Bagh section.
\end{abstract}

Keywords: Aquitanian, Burdigalian, benthic foraminifera, paleoenvironmental condition.

\section{Resumen}

La Formación Qom del Mioceno temprano está expuesta en la sección Bagh, al noreste de Isfahan, Irán Central, en donde sobreyace discordantemente a los depósitos del Oligoceno, y a su vez, está cubierta discordantemente por la Formación Upper Red. La formación está compuesta principalmente por depósitos de carbonatos (margas, facies de calizas margosas) y facies subordinadas de siliciclásticos. Los análisis bioestratigráficos de foraminiferos planctónicos permitieron reconocer dos zonas principales: 1. Zona de Globigerinoides primordiusen en la parte inferior de la sección, indicando una edad del Aquitaniano (Mioceno temprano) y 2. Zona de Globigerinoides trilobus en la parte superior de la Formación Qom, representando una edad del Burdigaliano (Mioceno temprano). 
La composición y abundancia de foraminiferos bentónicos y planctónicos fue examinada para la reconstrucción del paleoambiente y paleoecología. Los análisis de grupo (cluster) en modo Q, realizados para los foraminíferos bentónicos, permitieron subdividir la sección en tres grupos distintos de foraminiferos bentónicos: I. Cibicidoides ungerianus, en la parte inferior de la sucesión, indica predominio de ambientes neriticos internos. II. El grupo de Lenticulina orbicularis, en la parte media de la sección, es indicativa de ambientes neríticos mediosexternos y, III. El grupo de Elphidium-Amphistegina se registró en la parte superior de la formación y caracteriza un ambiente nerítico externo típico. Los foraminiferos planctónicos están dispersos en la parte superior de la sección, con una diversidad relativamente baja, indicando segmentos de plataforma marina abierta, mientras que los segmentos más someros que intervienen en la parte inferior de la sección están caracterizados por abundancia de foraminiferos bentónicos. Con base en estos grupos y como contribución a la paleoecología y paleoambiente, la alta abundancia con baja diversidad y talla pequeña de las testas de foraminiferos bentónicos, son características indicativas de un ambiente oligotrófico con alto contenido de nutrientes y alta oxigenación, con salinidad normal durante el Mioceno temprano en la sección Bagh.

Palabras clave: Aquitaniano, Burdigaliano, foraminíferos, bentónicos, condición paleoambiental.

\section{Introduction}

The Qom Formation was deposited in the interval from early Oligocene until the end of the early Miocene in northern and central Iran (Stöcklin and Setudehina, 1991; Abaie et al., 1964; Reuter et al., 2009; Yazdi et al., 2012) (Figure 1). The Qom Formation crops out along the Zagros fold belt (Figure 1), and is mainly composed of marine marls, limestone, gypsum and siliciclastics strata (Reuter et al., 2009). This basin has been examined since 1934 because of economic interests (Furon and Marie, 1939; Abaie et al., 1964). Most of those studies were carried out based on the distribution of larger assemblages of benthic foraminifers and sedimentary sequences (Furon and Marie, 1939; Furon, 1941; Furrer and Soder, 1955; Gansser, 1955; Dozy, 1944, 1945, 1955; Abaie et al., 1964; Bozorgnia, 1966; Kashfi, 1988; Aghanabati, 2003; Daneshian and Ramezani Dana, 2007; Zhu et al., 2007; Behforouzi and Safari, 2011). In general, the Lower Red Formation underlies the Qom Formation; on the other hand, this unit is conformably overlain by the Upper Red Formation (Stöcklin and Setudehina, 1991). The Qom Formation was divided by Furrer and Soder (1955) into six members: a. basal limestone, b. sandy marl, c. alternating marl and limestone, d. evaporate, e. green marl, and f. limestone. Abaie et al. (1964) based their study on the sedimentary cycles; they separated members $\mathrm{C} 1$ and $\mathrm{C} 3$ and increased the number of members to ten. Nogole-Sadat (1985) introduced at least three sedimentary cycles for the Qom Formation. Reuter et al. (2009) recognized two basins for the Qom Formation: the Qom backarc basin and Isfahan-Sirjan forearc basin (Figure 1). Subsequently, Oligocene-Miocene sedimentation in the Qom basin took place along a ramp carbonate platform including: intertidal, shelf lagoon, platform margin and open marine environments (Aghanabati, 2003; Seyrafian and Toraby, 2005; Daneshian and Ramezani Dana, 2007; Zhu et al., 2007; Behforouzi and Safari, 2011).

Small benthic foraminiferal assemblages from the Qom Formation have been poorly studied (Rahagi, 1980;
Daneshian and Aftabi, 2010). Hence, in this study we define important foraminiferal assemblages and reconstruct the paleoenvironmental setting of the Qom Formation in the Bagh outcrop.

\section{Geological setting and lithostratigraphy}

During the early-middle Miocene, periodic connections prevailed between the Mediterranean Sea, Paratethys province, Indo-Pacific region and the Atlantic Ocean (Rögl, 1998; Popov et al., 2004; Pippèrr, 2011). Intermittent seaway connections and regional closings were mainly driven by regional and global geotectonics and sea-level fluctuations (Rögl, 1998).

The Qom basin, in the Iranian plate, on the southeastern margin of the Paratethys, is an important basin for the interpretation of paleogeography and the construction of the Paratethys, the Mediterranean Sea to the Indo-Pacific region from the late Oligocene to early Miocene (Stöcklin and Setudehina, 1991; Rögl, 1998; Seyrafian and Toraby, 2005; Reuter et al., 2009, Khaksar and Maghfouri Moghaddam, 2007; Daneshian and Ramezani Dana, 2007; Mohammadi et al., 2011; Behforouzi and Safari, 2011; Yazdi et al., 2012).

The Bagh section is located at $32^{\circ} 57^{\prime} 61^{\prime \prime} \mathrm{N}$ and $52^{\circ} 01^{\prime} 95^{\prime \prime} \mathrm{E}, 55 \mathrm{~km}$ northeast of Isfahan (Isfahan-Sirjan forearc basin) (Figure 1). The investigated section is located along the NW-SE trend of the Qom-Zefreh fault. This fault formed during the closure of the Neotethys and the collision of the Arabian plate with the Iranian plate during Late Cretaceous time (Reuter et al., 2009).

Active tectonics led to the formation of complicated horst and graben structures and influenced thickness change in the Qom Formation, producing lateral variation of facies (Poroohan et al., 2009; Jalali and Feizi, 2010).

Lithologically, the Qom Formation is mainly composed of a thick interbedding of grayish yellow to yellowish white, highly fossiliferous marl and greenish grey, yellowish, friable, fossiliferous argillaceous to sandy 


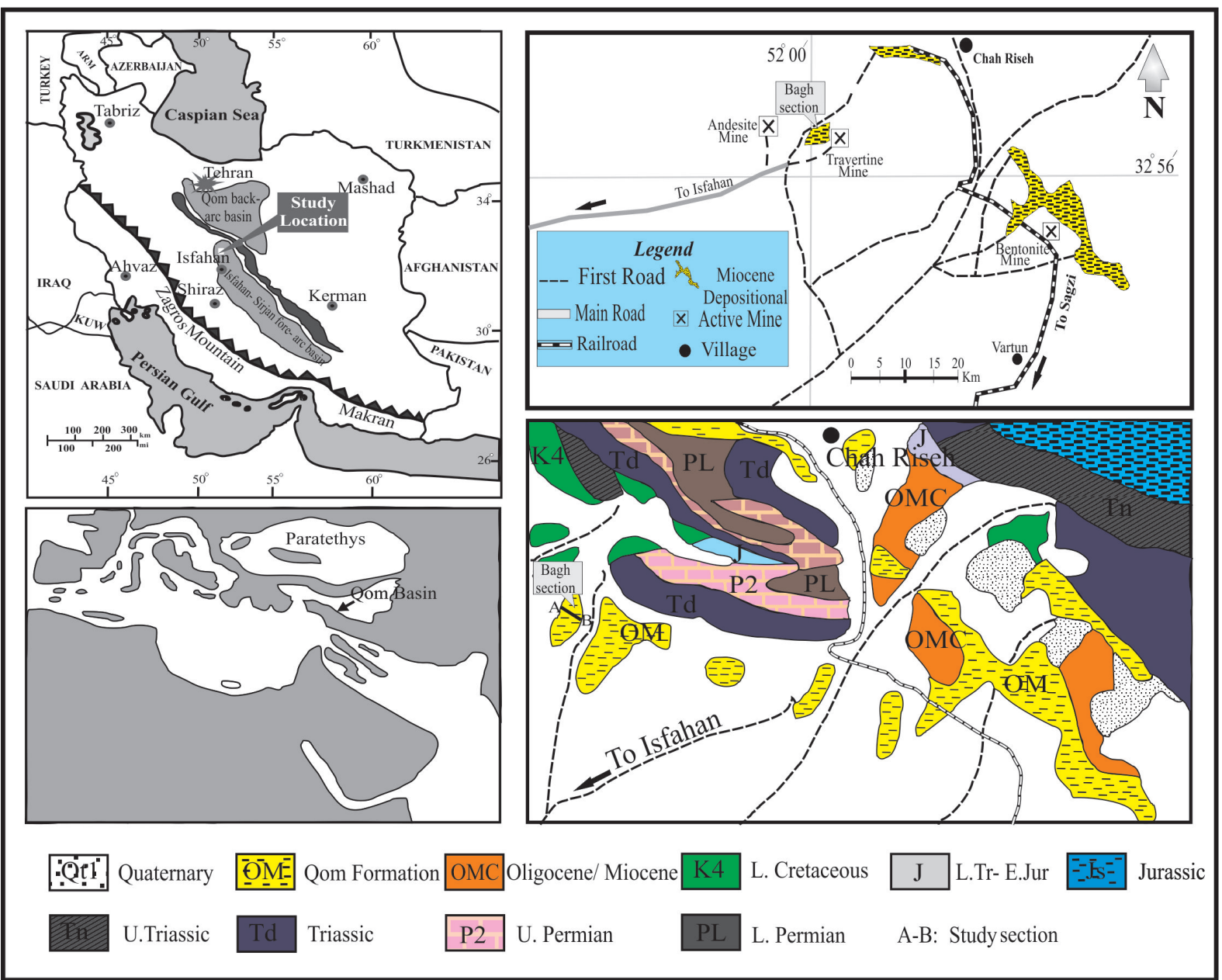

Figure 1. Location map of the study area in the Bagh section, northeast of Isfahan. a) Geological position of outcrop, the position of the Isfahan-Sirjan basin and the Qom basin in light gray and the volcanic arc in dark gray (modified from Schuster and Wieland, 1999; Reuter et al., 2009). b) Simplified road map of the area northeast of Isfahan, in the direction of Naein. c) Geographical overview of Paratethys Sea and position of Qom basin in the late Oligocene - early Miocene (modified from Reuter et al., 2007). d) Geographical map of the Bagh section (modified from Geological Survey of Iran by Zahedi and Amidi, 1978).

marly limestone. At the base, predominant greenish gray, fissile, fossiliferous calcareous shale is locally interbedded with thin beds of argillaceous limestone (Figure 2). The sequence is rich in macrofossils: Clypeaster confuses (Pomel, 1887), Clypeaster intermedius (Desmoulins, 1837), Eucidaris zeamays (Sismonda, 1842), Spondylus crassicosta (Lamarck, 1882), Echinolampulus ampulus (Fuchs, 1882), Turritella subarchimedies (Sacco, 1897) and Scutella sp. It is noteworthy to mention that the lowermost part of the Qom Formation yields large benthic foraminifers as Amphistegina lesson (d'Orbigny, 1843), Operculina complanata (Defrance, 1822), Operculina cf. bartschi (Cushman, 1921), Lepidocyclina tournoueri (Lemoine and Douville, 1904) Lepidocyclina sp., as well as coralline, red algae like Lithophyllum sp. and Lithothamnium sp. This type of macrofaunal and larger foraminiferal assemblages suggest that a shallow warm marine environment (inner neritic zone) prevailed during the early deposition of this unit. The thickness of the Qom deposits reaches $85 \mathrm{~m}$ in the
Bagh outcrop (Figure 2). The base of the Bagh outcrop is covered by the Lower Red Formation. The upper part of the Bagh section is composed of silty clay (channel deposition) overlying the Qom Formation with a sharp unconformity.

\section{Materials and methods}

The present study is based on the examination and investigation of about 30 samples collected from the Bagh section, northeastern Isfahan, Iran (Figure 1). For soft samples, about 100 grams of each were gently crushed and soaked in a solution of $10-20 \%$ hydrogen peroxide to accelerate the process of disintegration. The samples were washed several times through a set of sieves ranging between 63 to $162 \mu \mathrm{m}$, by using gently flowing water. The hard samples were first crushed and heated in metal bowl and then soaked in a solution of $10-30 \%$ hydrogen peroxide for at least two days, and then soaked in water. After that, 


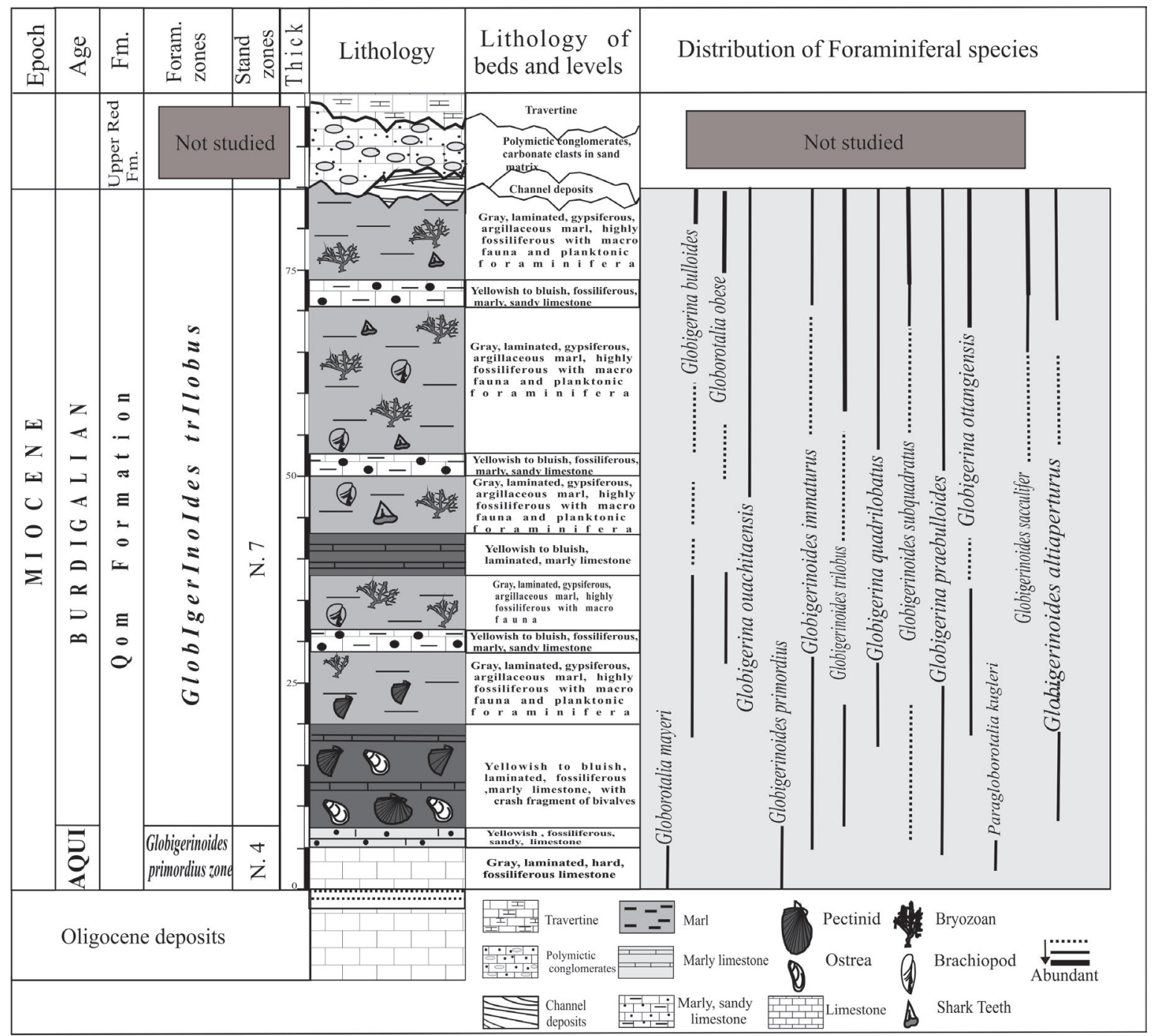

Figure 2. Schematic lithological succession of lower Miocene (Qom Formation) in Bagh area.

the washed residues were dried in an oven at $60{ }^{\circ} \mathrm{C}$ and sieved to retain the planktonic and benthic foraminifers. The picked samples were studied and documented by using SEM method. The identification and classification of foraminifers were performed according to Bolli et al. (1987) and Postuma (1971) schemes.

The benthic foraminifers are reliable indicators of paleoecological condition changes (Gebhardt, 1999; Drinia et al., 2007; Holcová and Zágoršek, 2008; Hohenegger et al., 2009; Zágoršek et al., 2009; Gupa et al., 2013).

The following data were calculated for paleoenvironment interpretation by using the computer software PAST (Holcová and Zágoršek, 2008; Pippèrr, 2011):

1) Oxygen contents were estimated using $B F O I=$ benthic foraminiferal oxygen index (Kaiho, 1994, 1999; Drinia et al., 2003, 2009, 2010; Mandic et al., 2002; Pippèrr, 2011).

$$
B F O I=O /(O+D) * 100
$$

Where $O$ is the number of oxic indicators and $D$ is the number of dysoxic indicators. Oxic, suboxic and dysoxic faunas were identified (Table 1) based on the schemes by Kaiho (1994), Baas et al. (1998), Stefanelli (2004), Van der Zwaan et al. (1990), and Holcová and Zágoršek (2008). Kaiho (1994) introduced high oxic $(3.0-6.0 \mathrm{~mL} / \mathrm{L})$ or $B F O I$ ranges values $100-50$, low oxic $(1.5-3.0 \mathrm{~mL} / \mathrm{L})$ with $B F O I$ ranges values $50-30$, suboxic $(0.3-1.5 \mathrm{~mL} / \mathrm{L})$ or $B F O I<$ 30 , dysoxic $(0.1-0.3 \mathrm{~mL} / \mathrm{L})$, and anoxic $(0-0.1 \mathrm{~mL} / \mathrm{L})$.

2) The percentage of euryhaline species can be indicated from salinity (Murray and Alve, 1999a; Pippèrr, 2011).

3) Paleodepth was estimated using $P / B$ ratios, where $P$ is the total number of planktonic foraminifers and $B$ is the total number of benthic foraminifers (Sen-Gupta and Machain-Castillo, 1993; Drinia et al., 2007; Holcová and Zágoršek, 2008). The relative abundance of the $P / B$ ratios is associated with distance from shore (Van der Zwaan et al., 1990; Wilson, 2003; Murray and Alve, 1999; Murray, 2006; Mandic and Harzhauser, 2003); the inner shelf environment (inner neritic) was defined with ratios of $<20 \%$, middle 
shelf (middle neritic) with ratios of $20-50 \%$ and $50-70 \%$ for the outer shelf (outer neritic) environment (Murray, 1991, 2006; Murray and Alve, 1999; Pippèrr, 2011).

4) Abundance of benthic foraminifers was estimated using the relationship between diversity index (Fisher's $\alpha$ ) and the total number of individuals (Hammer et al., 2001; Rai and Maurya, 2009).The fauna diversity is compared with fauna abundance. On the other hand, higher percentage indicates high diversity and it is contrasted with abundance (Pippèrr, 2011).

$$
S=\alpha \ln (1+N / \alpha)
$$

Where $S$ is the number of taxa, $N$ is the total number of individual taxa and $\alpha$ is the Fisher diversity index.

5) Relative abundance (\%) of cool and warm water species were used for estimation of paleotemperature (Bicchi et al., 2003; Holcová and Zágoršek, 2008; Hohenegger et al., 2009)

6) The Q-mode cluster analysis was used to statistically classify small benthic foraminifera (Hammer et al., 2001).

The systematic determination of the benthic foraminiferal species was based on the criteria of Loeblich and Tappan (1987a, b) and Tyszka (2001). The compilation of ecological preferences, including the depth-range for benthic foraminifers, is based on Murray and Alve (1999), Van Der Zwaan et al., (1990), Sgarrella and Moncharmont Zei (1993), Kaiho (1994, 1999), Zágoršek et al., (2009), Holcová and Zágoršek (2008), Pippèrr and Reichenbacher (2010), and Pippèrr (2011).

The specimens studied here are housed in the repository of Isfahan University, Faculty of Science under the code IUIB1-37 (Isfahan, University, Iran and Benthic Foraminifer).

\section{Planktonic Foraminiferal Biostratigraphy}

The detailed analysis of the planktonic and benthic foraminiferal assemblage obtained from the stratigraphic section in the Bagh area resulted in the recognition of two planktonic foraminiferal zones. The identified biostratigraphic zones are locally correlated with their equivalent biozones in Iran and with the equivalent warm and tropical water areas with special emphasis on the Mediterranean region. The stratigraphic distributions of the identified taxa is represented in Figure 2; scanning electron micrographic were also prepared for the important species and included in two plates (Figures 6,7).

It is noteworthy to mention that the boundary zones in the study sections are defined on the basis of datum events or first and last appearance of the zonal taxa which is more applicable in the Mediterranean region (Iaccarino and Salvatorini, 1982; Iaccarino et al., 2005; Berggren and Pearson, 2005). In this study the late Oligoceneearly Miocene boundary is defined on the basis of the first occurrence of Globigerinoides primordius and Paragloborotalia kugleri together. Following is a brief description of the identified biozones from base to top based on the zonation represented by Iaccarino and Salvatorini (1982):

\subsection{Globigerinoides primordius Zone.}

Category: Interval zone.

Age: Aquitanian (early Miocene).

Author: Blow (1969) emended here to fit the studied material.

Definition: Interval from first occurrence of the zonal marker Globigerinoides primordius to the first occurrence of Globigerinoides trilobus.

Planktonic association: This zone is characterized by low frequency and low diversity of planktonic foraminiferal taxa. The most common assemblage includes: Globigerinoides primordius (Blow and Banner, 1962), Globigerinoides immaturus (Le Roy, 1939), Paragloborotalia kugleri (Bolli, 1957), Globigerinoides subquadratus (Brönnimann, 1954), Globorotalia mayeri (Cushman and Ellisor, 1939), and Globigerina praebulloides (Blow, 1959).

Remarks: In the examined material, the Globigerinoides primordius Zone represents the oldest Miocene planktonic foraminiferal zone recorded. Some authors believed that the Oligocene-Miocene boundary should be established at the first evolutionary occurrence of the genus Globigerinoides, especially the appearance of Globigerinoides primodius (Blow, 1979; Bolli et al., 1987). Others considered that Gs. primordius makes its first occurrence as early as the Paragloborotalia kugleri zone of late Oligocene age (Stainforth et al., 1975; Berggren et al., 1995). Bolli et al. (1987) recognized that determination of the OligoceneMiocene biozone is dependent on the local environmental conditions and therefore stratigraphically less reliable. This controversy motivated these workers to redefine the lower boundary of the lowest Miocene zone. Iaccarino (1985) overcame this problem and considered the first occurrence of the Globoquadrina dehiscens dehiscens to delineate the lowest Miocene biozone. But in the present study, it is suggested that the lowest Miocene biozone could be referred to as the Gs. primordius zone, since Globoquadrina dehiscens dehiscens is not recorded. This zone could be correlated with the standard planktonic foraminiferal zone N4 of Blow (1969). In the present study, the last extinction of the nominated zonal marker is stratigraphically reliable to delineate the late Oligocene-early Miocene boundary. Whereas the next zonal marker, Globigerinoides trilobus, is not recorded in this zone and makes its first occurrence with the last extinction of Gs. primordius. This zone could be correlated to M1 of Berggren et al. (1995).

Occurrences: This zone is generally recorded in the Qom Formation. It is recorded in the lower part of the Bagh section from $0-5 \mathrm{~m}$. This zone is considered as Aquitatian in age (early Miocene) on the basis of the total range of the zonal taxa. 


\subsection{Globigerinoides trilobus Zone}

Category: Interval zone.

Age: Burdigalian (early Miocene).

Author: Bizon and Bizon (1972).

Definition: This zone occupies the interval from last occurrence of Globigerinoides primordius to the last occurrence of Globigerinoides trilobus (Postuma, 1971).

Planktonic association: This zone is characterized by the high frequencies and moderate diversity of planktonic foraminiferal species e.g. Globigerinoides trilobus (Reuss, 1850), Gs. immaturus (Le Roy, 1939), Gs. sacculifer (Brady, 1877), Gs. Subquadratus (Brönnimann, 1954), Gs. altiaperturus (Bolli, 1957), Globigerina praebulloides (Blow, 1959), Globigerina bulloides (d’Orbigny, 1826), Globigerina ouachitaensis (Howe and Wallace, 1932), Globigerina ottangiensis (Rögl, 1969), and Globorotalia obese (Bolli, 1957).

Remarks: This zone is characterized by moderate diversity of planktonic foraminifers. Such occurrence suggests development under open, deep marine environments (middle to outer neritic zone). This zone is strongly matched with the standard planktonic foraminiferal zone N7 of Blow (1969). The absence of the Catapsydrax dissimilis/ Globigerinoides altiaperturus Zone of early Burdigalian age may be attributed to ecological changes during the deposition of the Qom Formation. This zone could be correlated with M4 of Berggren and Pearson (2005).

Occurrence: This zone is generally recorded in the Qom Formation, in the upper part of the section, from 5-85 m. This zone is considered as Burdigalian (early Miocene) age on the basis of the total range of the Globigerinoides trilobus zonal taxon.

\section{Ecology of Planktonic Foraminifers}

Abundance, diversity and composition of foraminifers are strongly controlled by temperature. According to Spezzaferri (1995), Bicchi et al. (2003) and Holcová and Zágoršek (2008), the Globigerinoides primordius, Gs. sacculifer, Gs. quadrilobatus and Gs. trilobus are commonly indicative of warm waters, whereas Globigerinoides immaturus, Globigerina praebulloides, and Globigerina ottangiensis are considered to be cool-water indicators (Table 1). Indeed, Spezzaferri (1995) considered Globigerina ottangiensis and Globigerina praebulloides as indicators of high productivity (Rögl and Spezzaferri, 2003).

\section{Ecology and classification of benthic foraminifers by cluster techniques}

The microfossil assemblages of the Qom Formation have been described by many authors based on large benthic foraminifer distribution (Schuster and Wielandt, 1999;
Table 1. Paleotemperature marker column (Spezzaferri et al., 2002; Holcová and Zágoršek, 2008).

\begin{tabular}{lcc}
\hline \multicolumn{1}{c}{ Paleotemperature markers } & $\begin{array}{c}\text { Spezzaferri } \text { et al ., } \\
\mathbf{2 0 0 2}\end{array}$ & $\mathbf{2 0 0 9}$ \\
\hline Globorotalia mayeri & warm & warm - temperate \\
Globigerina bulloides & cold & cold \\
Globorotalia obese & warm & - \\
Globigerina ouachitaensis & warm & - \\
Globigerinoides primordius & warm & - \\
Globigerinoides immaturus & cold & cold \\
Globigerinoides trilobus & warm & warm \\
Globigerina quadrilobatus & warm & warm \\
Globigerinoides subquadratus & warm & - \\
Globigerina praebulloides & cold & cold \\
Globigerina ottangiensis & cold & cold \\
\hline
\end{tabular}

Abaie et al., 1964; Seyrafian and Toraby, 2005; Reuter et al., 2009; Daneshian and Ramezani Dana, 2007; Mohammadi et al., 2011; Behforouzi and Safari, 2011). The Qom Formation can be correlated with the lower part of Asmari Formation (Zagros fault belt) (Figure 1) and was assigned a Rupelian to Burdigalian age. In the Bagh outcrop, benthic foraminifer assemblages are generally abundant and small in size. A summary of the paleoenvironment preference of the dominant benthic foraminifers from the Bagh Section is shown in Table 2. The ecology of benthic foraminifers was studied by Spezzaferri et al. (2002) and Bicchi et al. (2003).

The Lenticulina sp. is dominant and a large-sized genus $(>250 \mu \mathrm{m})$. The benthic foraminifer assemblages increase in diversity upwards (Figures 3 and 4). In order for the best analysis of paleoenvironment, we used cluster modeling. Q-Mode clustering corresponding to Ward's minimum variance method and the percentage contribution of benthic foraminifers distinguished three major clusters (Figures 3, 4 and 5).

I) The Cibicidoides ungerianus cluster is recorded in samples A1 - A13. This cluster is characterized by the abundance of Cibicidoides ungerianus (39\%) and relatively common occurrence of Bolivina digitalis (16\%) and Cibicidoides sp. (18\%). The hyaline taxa are abundant whereas agglutinated taxa are represented by Textularia agglutinans (11\%) and Quinqueloculina triangularis (4 $\%)$ that are dominated by small-sized test. Less abundant species $(0-3 \%)$ are represented by Lenticulina orbicularis, Lenticulina inornata, Uvigerina sp. Fisher's $\alpha$ diversity is small $(\alpha=3.2)$ and indicates high frequency. Planktonic foraminifer abundance becomes relatively rare toward the upper position of this cluster and diversity is low $(3-6 \%)$. $\mathrm{P} / \mathrm{B}$ ratios are about $3.38-17$ (Figures 5 and 7). $\mathrm{BFOI}$ is high, from $64.61-89.4$, and indicates a highly oxygenic environment (Murray and Alve, 1999; Murray, 2006; Wilson, 2003; Pezelj et al., 2007, 2012). The depth estimate for this cluster matches closely the depths given by Holcová and Zágoršek (2008) and is approximately $35-70 \mathrm{~m}$. 
II) The Lenticulina orbicularis cluster is dominated by only six samples, from A14 - A19. Lenticulina orbicularis is the most abundant taxa ( $32 \%)$, in association with Cibicidoides lobatulus (16\%), Cibicidoides sp. (18\%), Lenticulina inornata (10\%), and Cibicidoides ungerianus $(5 \%)$ whereas other minor taxa $(1-2 \%)$ are Uvigerina costata, Textularia agglutinans, Quinqueloculina triangularis, Lenticulina maynae and Heterolepa dutemplei (Figures 6 and 7).

The Shannon-Weaver index of diversity of assemblage

Table 2. Paleoecological preference of the dominant benthic foraminifera in the Bagh succession modified after Rögl and Spezzaferri (2003)

\begin{tabular}{|c|c|c|c|c|c|}
\hline Species & Environment & Preferred depth range (m) & Preferred substratum & Living strategy & Dysoxic / Oxic markers \\
\hline Cibicidoides ungerianus & Inner shelf & Abundant $30-50 \mathrm{~m}$ & Hard substrates & Epiphytic & Oxic \\
\hline Cibicidoides sp. & Shelf to bathyal & From $50 \mathrm{~m}$ down & Hard substrates & Epiphytic & Oxic \\
\hline Cibicidoides lobatulus & Inner shelf & $30-50 m$ & $\begin{array}{c}\text { Hard substrates - muddy } \\
\text { sand }\end{array}$ & Epiphytic & Oxic \\
\hline Uvigerina $\mathrm{sp}$. & Shelf to bathyal & $\begin{array}{l}100 \mathrm{~m} \text { to }>4500 \mathrm{~m} \text {, rarely } \\
\text { shallower than } 100 \mathrm{~m}\end{array}$ & Mud & $\begin{array}{l}\text { Shallow endopelic, } \\
\text { rarely epiphytic }\end{array}$ & $\begin{array}{c}\text { Suboxic and high organic } \\
\text { matter }\end{array}$ \\
\hline Heterolepa dutemplei & Shelf- upper bathyal & $25-500 m$ & Mud & & Oxic \\
\hline Bolivina dilatata & Inner shelf to bathyal & Abundant from $50-200 \mathrm{~m}$ & Mud & Shallow endopelic & Low oxygen \\
\hline Lenticulina orbicularis & Middle- outer shelf & Abundant from $50-100 \mathrm{~m}$ & Mud & & Suboxic \\
\hline Lenticulina inornata & Middle- outer shelf & $\begin{array}{l}\text { Down to } 50 \mathrm{~m} \text { more abundant } \\
\qquad 50-300 \mathrm{~m}\end{array}$ & Mud & & Suboxic \\
\hline Lenticulina $\mathrm{sp}$. & Outer shelf and bathyal & From $20 \mathrm{~m}$ down & Mud & & Suboxic \\
\hline Lenticulina maynae & Middle- outer shelf & $\begin{array}{l}\text { Down }-50 \mathrm{~m} \text { more abundant } \\
50-300 \mathrm{~m}\end{array}$ & Mud & Epiphytic & Suboxic \\
\hline Elphidium sp. & Inner shelf & $0-50 \mathrm{~m}$ & Mud and sand & Epiphytic & Oxic \\
\hline Elphidium fichtelianum & Inner shelf & $0-110 \mathrm{~m}$ & Mud and sand & Epiphytic & Oxic \\
\hline Amphistegina planorbis & Inner shelf & $0-110 \mathrm{~m}$ & Mud & Epiphytic & \\
\hline
\end{tabular}
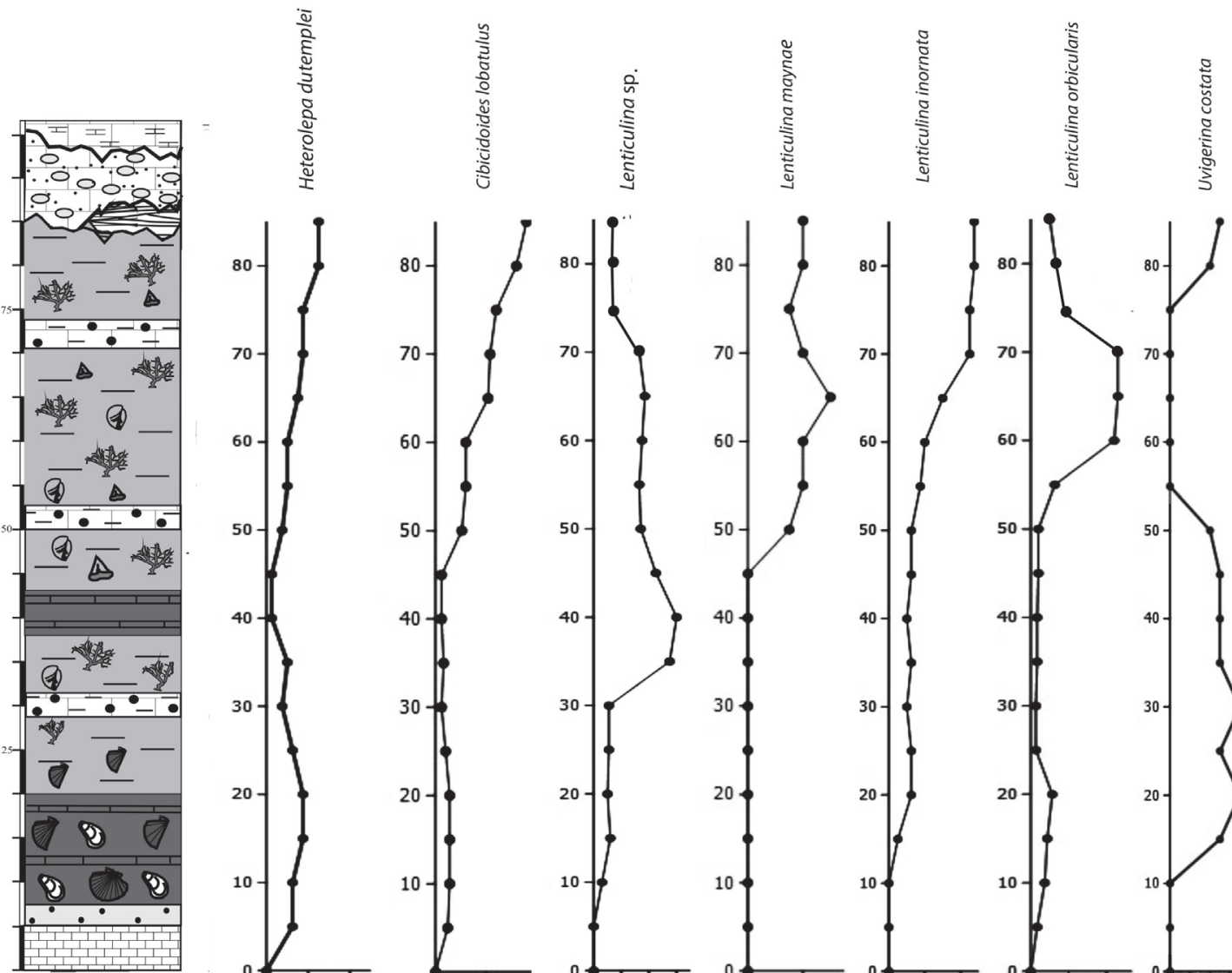

ํำ
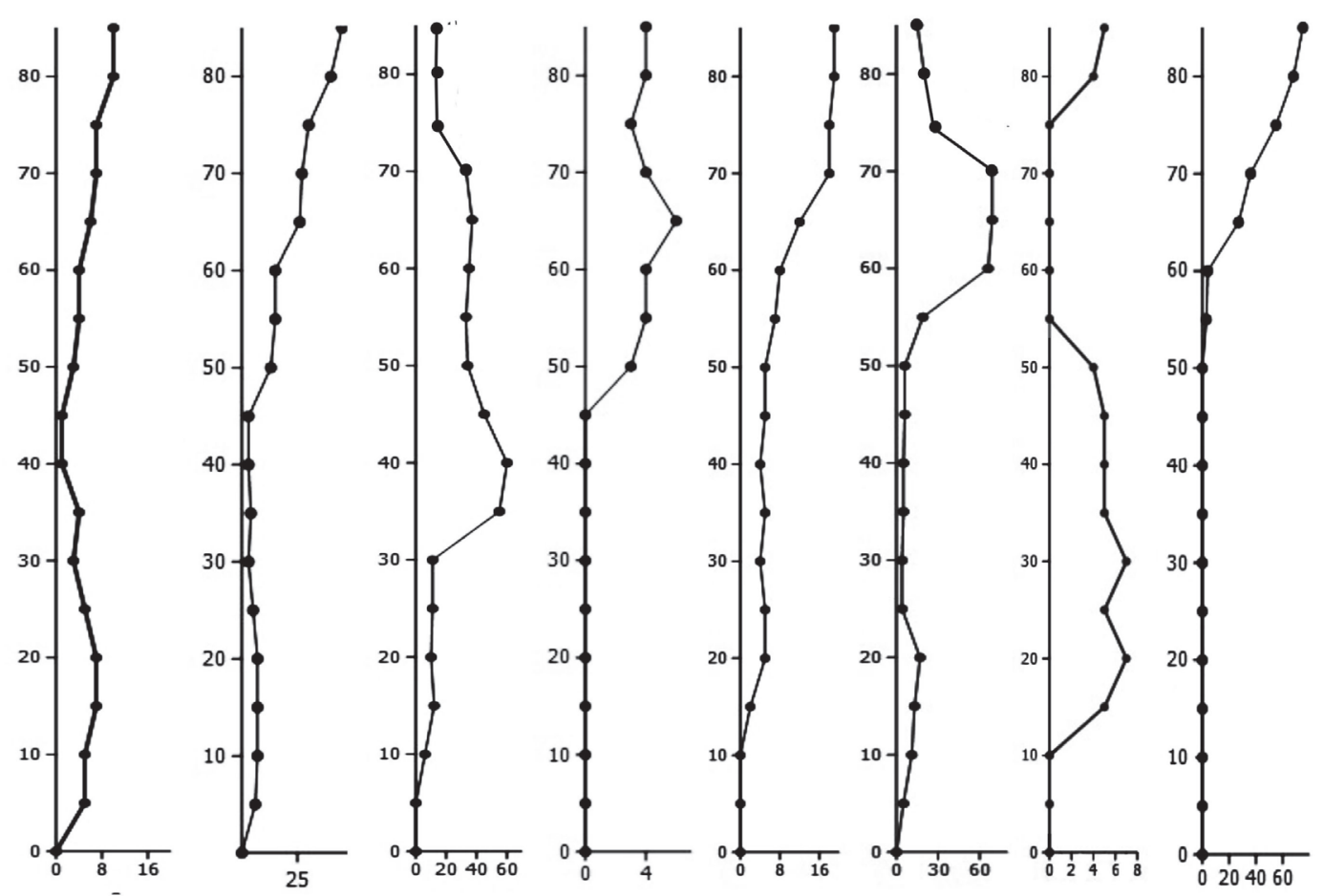

Figure 3. Relative frequency data for the selected benthic foraminifera. 


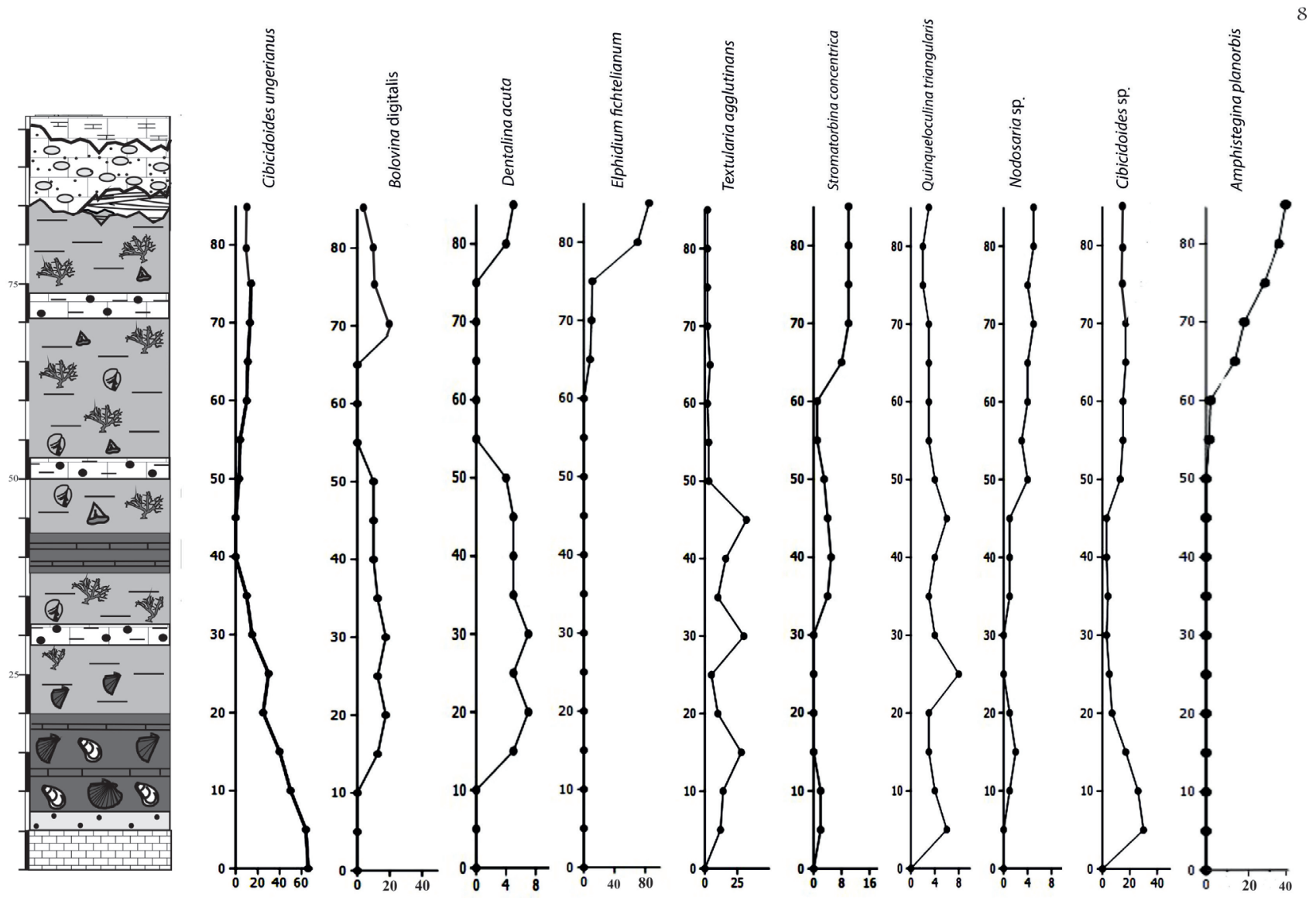

Figure 4. Relative frequency data for the selected benthic foraminifera.
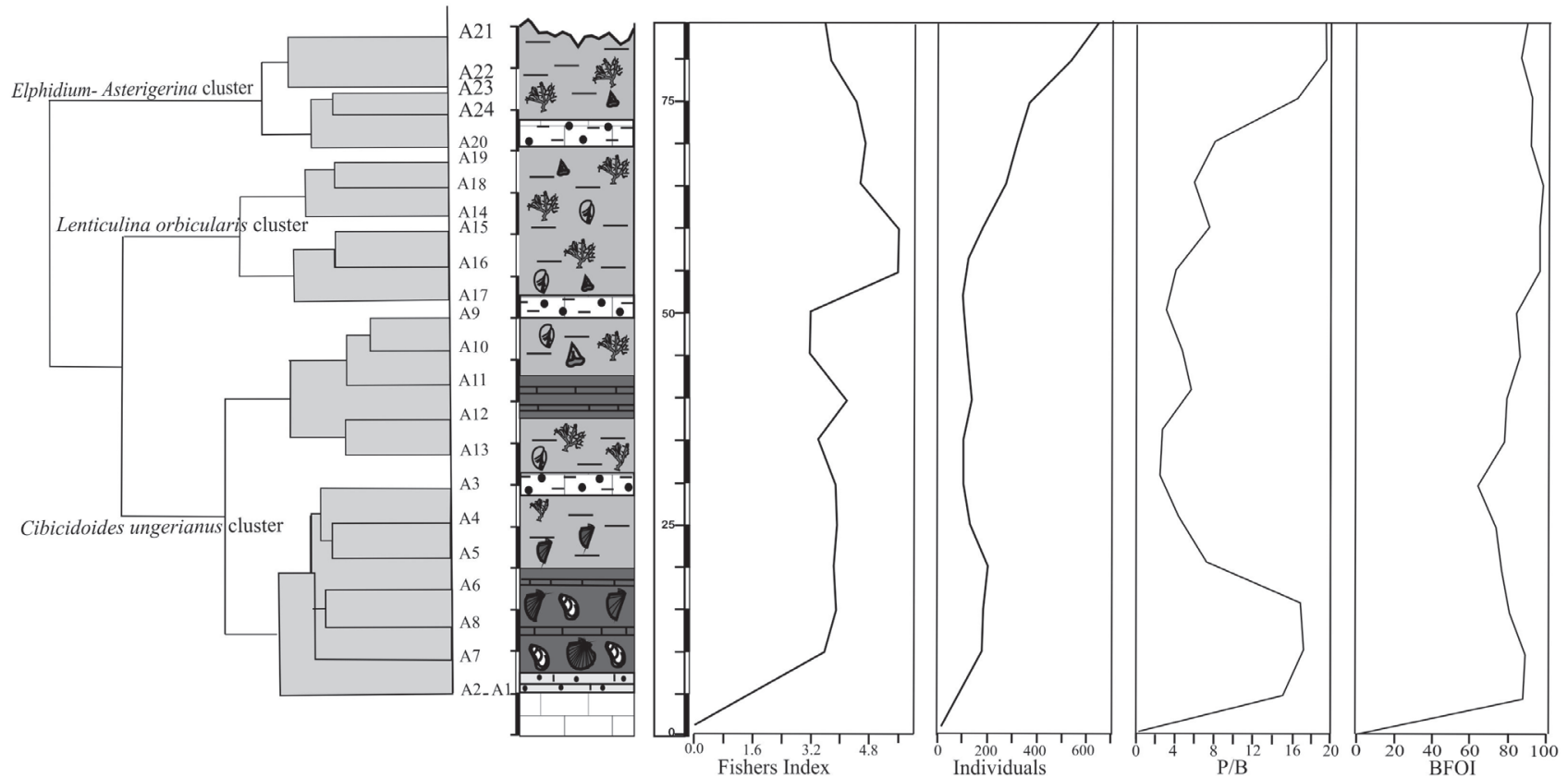

Figure 5. Classification of benthic foraminifer samples produced by Q-mode cluster analysis and distribution patterns of the Fisher's $\alpha$ diversity. Number of individuals, $\mathrm{P} / \mathrm{B}$ ratios and Oxygen Index $(B F O I)$. 


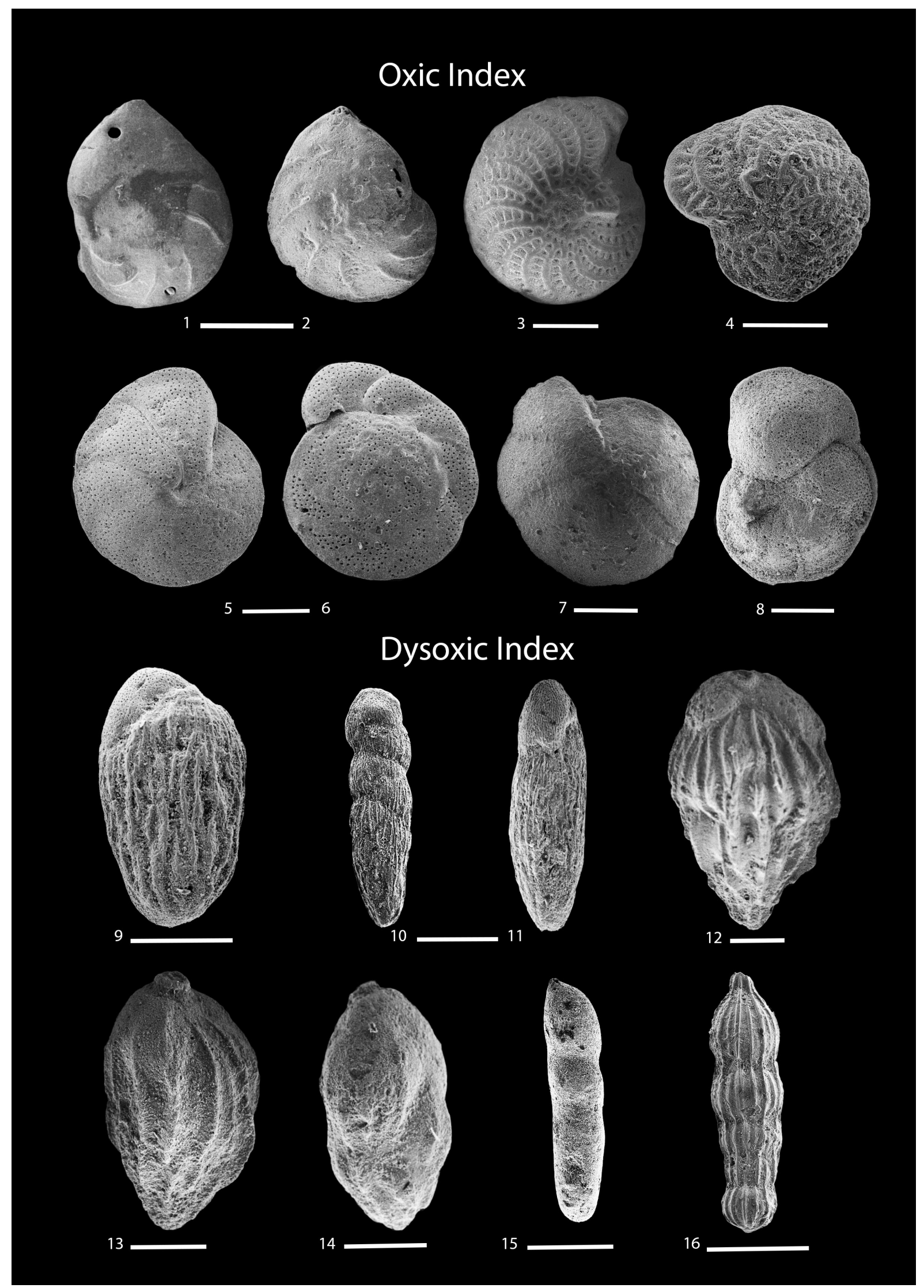

Figure 6. Benthic foraminifera IUIB1-16 (oxic- dysoxic indicator): (1) Lenticulina maynae; (2) Lenticulina inornata; (3) Elphidium fichtelianum; (4) Elphidium sp.; (5 - 6) Heterolepa dutemplei; umbilical view (5) and spiral view (6); (7) Cibicidoides ungerianus; (8) Cibicidoides lobatulus; (9) Bolivina sp.; (10-11) Bolivina digitalis; (12-14); Uvigerina costata; (15) Laevidentalina communis; (16) Amphicoryna sp. Scale bars $=200 \mu \mathrm{m}$. 
is relatively moderate (Figure 5). The mean percentage of planktonic foraminifers is very low $(7 \%)$ and $\mathrm{P} / \mathrm{B}$ ratios reaches mean values of $3.84-8$ (Figure 5). Diversity of benthic foraminifers as well as planktonic foraminifers is low. All species belong to hyaline group, and agglutinated foraminifers of very small size decrease in number $(2 \%)$. BFOI ranges between 85.3 and 98 (Figures 5 and 6). Besides, sponge spicules, fragile bryozoan remains, and spine and fish teeth become abundant. The estimated paleodepth for this cluster based on foraminifer living depth is about 50 - 100 m (Murray, 1991; Holcová and Zágoršek, 2008; Pippèrr and Reichenbacher, 2010).

III) The Elphidium-Amphistegina cluster is recorded in the upper part of section $(70-85 \mathrm{~m})$. This cluster differs from other clusters and contains five samples, A21 - A24 (Figure 5). The assemblage is dominated by Elphidium fichtelianum / Elphidium sp. (25\%) and Amphistegina planorbis $(13 \%)$, and is accompanied by small Lenticulina inornata (9\%). Fisher's $\alpha$ diversity reaches values $4-5.1$ (Figure 5). The percentage of planktonic foraminifers reaches up to $21 \%$ with $\mathrm{P} / \mathrm{B}$ ratios of $4-19.4$ and the $B F O I$ values are around $87-91$ (Figure 5). Bryozoan and brachiopods are abundant with more diversity throughout this interval.

\section{Paleosalinity}

The interpretation of paleosalinity in the Bagh outcrop was measured based on biota assemblages. Frequency of bryozoans, brachiopods, echinoids and bivalves indicates normal marine salinity. In general, widespread uryhaline taxa (e.g. Cibicidoides, Lenticulina and Elphidium), along the profile indicate that normal sea-water salinity dominated. Low diversity, high abundance and small test- sized of foraminifers suggest a stable environment.

\section{Paleoenvironment}

Benthic foraminifer distribution and diversity is mainly dependent on oxygen concentration in pore water and organic flux (Gebhardt, 1999; Drinia et al., 2003) although the effect of temperature, water depth and salinity cannot be disregarded (Kaiho, 1994; Baas et al., 1998; Gebhardt, 1999; Pippèrr and Reichenbacher, 2010; Gupa et al., 2013). High oxygen content and organic flux cause eutrophic conditions. In such an environment, benthic foraminifers present low diversity and high abundance, which lead to oxygen consumption in bottom waters. A high percentage of benthic foraminifers indicates high productivity in a shallow basin or a lower sedimentation rate (Tyszka, 2001). The environmental interpretation follows the criteria established by Spezzaferri (1995) and Spezzaferri et al. (2002).

The distribution of benthic foraminifers in the Bagh succession is depicted in Figures 3 and 4. In the Bagh outcrop, Lenticulina and Cibicidoides are more abundant and indicate tolerance to high-oxygen $(B F O I=60-100)$ conditions (Kaiho, 1994; Van der Zwaan et al., 1990; Baas et al., 1998; Wilson, 2003; Stefanelli, 2004; Drinia et al., 2007, 2010; Holcová and Zágoršek, 2008; Pippèrr and Reichenbacher, 2010; Gupa et al., 2013). Cibicidoides ungerianus assemblages are found in the lower part of the Bagh section. Textularia agglutinans and Quinqueloculina triangularis are present in the lower part whereas in the middle and upper parts of the Bagh section gradually become more scarce. In the modern oceans, Cibicidoides species live in an inner neritic environment, approximately between 50 and $70 \mathrm{~m}$ in depth (Wilson, 2003; Holcová and Zágoršek, 2008; Pippèrr and Reichenbacher, 2010; Pippèrr, 2011), and in relatively high-energy environments of normal salinity in tropical to warm-temperate seas (Holcová and Zágoršek, 2008).

The paleodepth was estimated by percentage of planktonic foraminifers $(\mathrm{P} / \mathrm{B})$. According to Van der Zwaan et al. (1990), $\mathrm{P} / \mathrm{B}$ ratios of $<20 \%$ suggest inner shelf (inner neritic) environments (Pippèrr and Reichenbacher, 2010; Pippèrr, 2011).The high frequency stands for productivity and this was the result of an immense flood flux. This hypothesis is supported by high percentage of Cibicidoides ungerianus and Cibicidoides sp. in combination with high abundance of Bryozan bivalve fragments (Spondylus coccineus, Pecten burdigalensis, Ostrea lamellose, Ostrea edulis and Ostrea gryphoides) and echinoid spines (Clypeaster intermedius, Arbacina sp., Eucidaris zaemays, Stylocidaris? Polyacantha and Prionocidaris sp.). This assemblage supports deposition in shallow, inner neritic environments (Drinia et al., 2007, 2010; Holcová and Zágoršek, 2008; Pippèrr, 2011).

The middle part of the Bagh section is dominated by Lenticulina species. High frequency of Lenticulina taxa refer to a stable and suboxic environment $(B F O I>60)$ (Figure $6)$. The percentage of planktonic foraminifers is low $(\mathrm{P} / \mathrm{B}$ $<10 \%$ ), therefore, it can be compared to sheltered coastal environments (Gibson, 1989; Drinia et al., 2007).

Frequency of Lenticulina, with low percentage of Cibicidoides genus, suggests possible slight oxygen depletion at the sea floor. Lenticulina orbicularis has been identified from middle-outer neritic to above the CCD (Pezelj et al., 2007, 2012). Lenticulina orbicular, in association with Cibicidoides sp., Lenticulina inornata, Cibicidoides lobatulus and Cibicidoides ungerianus reflect deposition in middle neritic waters with depths around $50-100 \mathrm{~m}$. High abundance and low diversity are typical of eutrophic conditions. Finally, in the upper part of the Bagh succession, Elphidium fichtelianum / Elphidium sp. and Amphistegina planorbis are dominant genera and indicate deposition in an inner-middle neritic environment, while the percentage of planktonic foraminifers more than $10 \%$. This indicates the presence of an outer neritic environment. There is no evidence of benthic foraminifers typical of deep-water habitats while the abundance of 


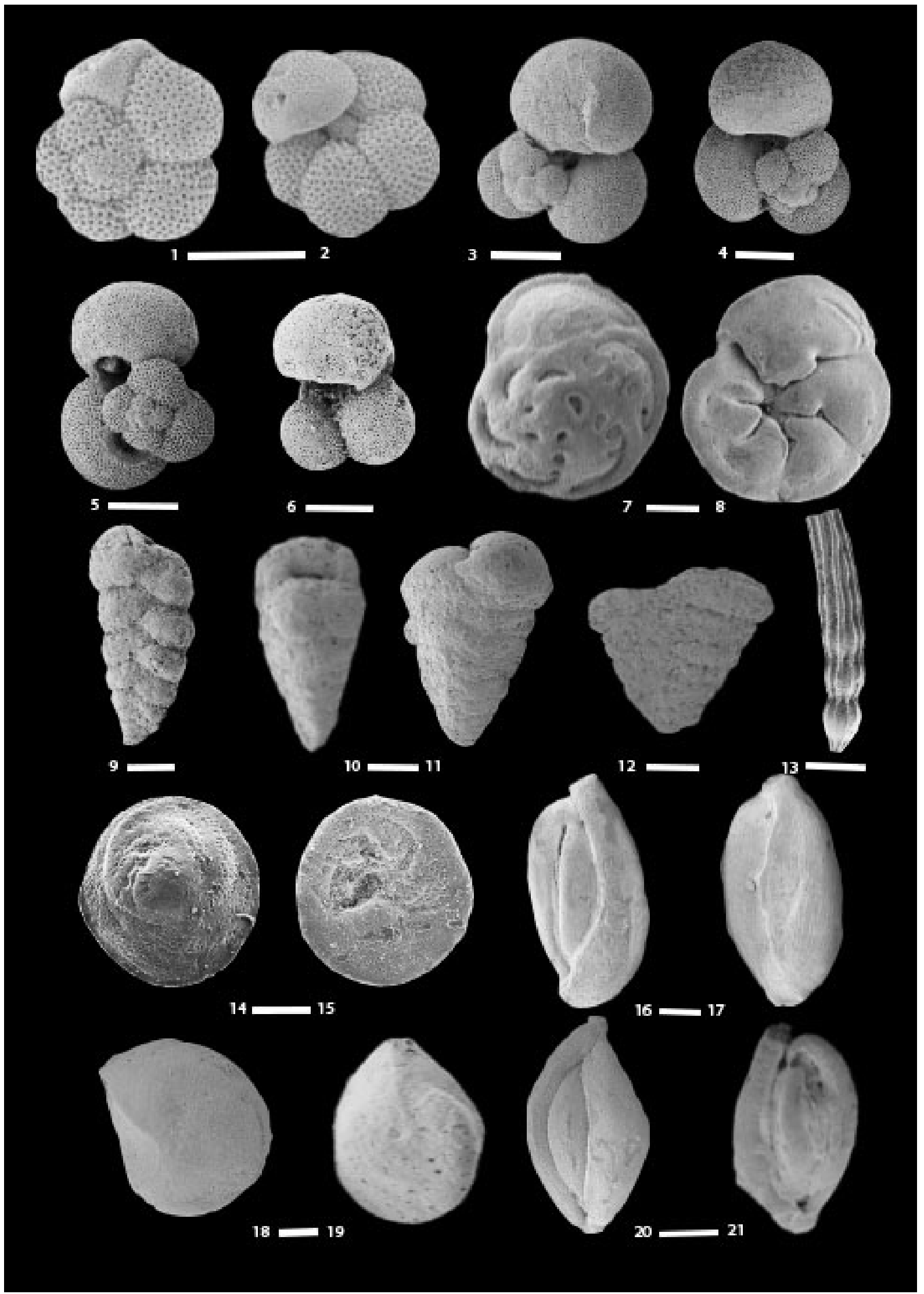

Figure 7. Benthic foraminifera IUIB17-37: (1 - 2) Globigerina ottangiensis; (3) Globigerinoides premordius; (4 - 6) Globigerinoides trilobus; (7 - 8) Stomatorbina concentrica; $(9-11)$ Textularia agglutinans; Lateral view $(9,11)$ and aperture view $(10) ;(12)$ Textularia mayori; (13) Dentalina acuta; (14 - 15) Sterigerinata planorbis; (16 - 17) Triloculina sp.; (18 - 19) Lenticulina inornata; $(20-21)$ Quinqueloculina triangularis. Scale bars $=200 \mu \mathrm{m}$. 
Globigerinoides trilobus suggests an outer neritic to upper bathyal paleodepth (Murray and Alve, 1999; Wilson, 2003). Most of the Elphidium genus shows strong diversity and dissolution with small-size test. It can be concluded that the difference in the paleodepth, determined by the percentage of planktonic foraminifers and habitat preference of benthic foraminifers, suggest the post-mortem transport of euryhaline species to outer neritic environments. Larger tests and complete development of planktonic foraminifers indicate the more stable ecological conditions in this environment. Abundance of Globigerinoides trilobus, along this profile indicates warm-temperate to temperate climate (Van der Zwaan et al., 1990; Stefanelli, 2003), while the Globigerina group is abundant in upwelling areas, where cool waters bring nutrients to the surface and cause high productivity (Rögl and Spezzaferri, 2003). The highest abundance of Globigerinoides species is observed in the upper part of the Bagh succession. This fact can represent interspersion of local upwelling conditions or nutrients brought by fluvial currents. A similar condition has been reported from the western and central part of Paratethys (Rögl and Spezzaferri, 2003; Pezelj et al., 2012). AndreyvaGrigorovich et al. (1997) argued that, in the inner-middle neritic zone, the highly eutrophic environment may have been influenced by intensified upwelling of deeper waters and suggested that depths of 60 meters or more are needed to accommodate ocean upwelling dynamics when the winds blow parallel to the coast (Stassen et al., 2009). Paleodepth estimations of about $50-100 \mathrm{~m}$ and the presence of coolwater planktonic foraminifers support the scenario of local upwelling conditions in the succession.

\section{Conclusions}

The lower Miocene carbonate deposits of the Qom Formation are well exposed in the Bagh section, Northeast Isfahan (Central Iran). Lithostratigraphically, the formation unconformably overlies the Oligocene Lower Red Formation and underlies the middle Miocene Upper Red Formation. A systematic study and the taxonomic investigations of the foraminifers, as well as the stratigraphic vertical distribution of the planktonic foraminifers, resulted in the determination of the following planktonic foraminiferal zones, from base to top of the study succession:

1. The Globigerinoides primordius Zone spanning the lowermost part of the section and assigned to the Aquitanian (early Miocene);

2. The Globigerinoides trilobus Zone covering the uppermost part of the Qom Formation and assigned a Burdigalian age (early Miocene). The absence of Catapsydrax dissimilis Zone of early Burdigalian age may be attributed to ecological changes during the deposition of the Qom Formation.

Composition and abundance of calcareous benthic and planktonic foraminifers were examined for reconstruction of several environmental parameters such as oxygen content, bathymetry (paleodepth), temperature and salinity. The Q-mode cluster analyses performed on the benthic foraminifers led to the subdivision of the section into three distinct benthic foraminiferal clusters:

I. The Cibicidoides ungerinanus cluster is dominated and characterized by the predominance of eutrophic, warm water, marine salinity, highly oxygenated bottom waters, and species typical of high dissolved oxygen values (High Oxic Index).

II. The Lenticulina orbicularis cluster is represented in the middle part of section by only six samples characterized by deep-infaunal dysoxic and suboxic species indicative of middle neritic environments and strongly related to dissolved oxygen values and increased water depth.The benthic association with this cluster indicates warm water with normal marine salinity conditions.

III. The Elphidium-Amphistegina cluster is recorded in the upper part of the Bagh section and is characterized by a typical outer neritic environment.

The study sediments also showed an abundance of Cibicidoides ungerianus, Textularia agglutinans, Quinqueloculina triangularis, Lenticulina orbicularis, Lenticulina inornata, Uvigerina costata, Lenticulina maynae, Heterolepa dutemplei, Bolivina digitalis, Cibicidoides sp., Elphidium fichtelianum, Elphidium sp., and Amphstegina planorbis, which reflect an inner-middle neritic environment while the abundance of planktonic foraminifers in the upper succession refers to an outer neritic environment. Within outer neritic environment transportation of shallow benthic foraminifers to deeper water can clearly be observed. Abundance of epifaunal biota as well as lower species diversity and higher population of this community demonstrate a highly oxic environment, warm with normal salinity.

\section{Acknowledgements}

The paper is a part of PhD study at Ferdowsi University in Mashad, Iran. We greatly appreciate the help of Dr. Andrea Benedetti of Sapienza University of Rome for the identification of larger benthic foraminifers. Indeed, we would like to thank Dr. Maria Aleksandra Bitner from the Polish Academy of Science, Institute of Paleobiology, for her great efforts in identifying Brachiopods. Finally, we are greatly indebted to the University of Isfahan for technical support.

\section{References}

Abaie, I., Ansari, H.J., Badakhshan, A., Jaafari, A., 1964, History and development of the Alborz and Sarajeh fields of Central Iran: Bulletin of Iranian Petroleum Institute, 15, 561-574.

Aghanabati, A., 2003, Geology of Iran: Geological Survey of Iran, 586 p. (in Persian). 
Andreyva-Grigorovich, A.S., Kulchytsky, Y.O., Gruzman, A.D., Lozynyak, P.Y.,Petrashkevich, M.I., Portnyagina, L.O., Ivanina, N.V., Smirnov, S.E., Trofimovich, N.A.,Savitskaya, N.A., Shvareva, N.J., 1997, Regional stratigraphy scheme of Neogene formation of the Central Paratheys in the Ukraine: Geologica Carpathica, 48, 123-136.

Baas, J.H., Schönfeld, J., Zahn, R., 1998, Mid-depth oxygen drawdown during Heinrich events: Evidence from benthic foraminiferal community structure, trace fossil tiring, and benthic $\delta^{13} \mathrm{C}$ at the Portuguese Margin: Marine Geology, 152, 25-55.

Behforouzi, E., Safari, A., 2011, Biostratigraphy and paleoecology of the Qom Formation in Chenar area (northwestern Kashan), Iran: Revista Mexicana de Ciencias Geológicas, 28(3), 555-565.

Berggren, W.A., Kent, D.V., Aubry, M.P., Hardenbol, J., 1995, Geochronology, time scales and global stratigraphic correlation: Society for Sedimentary Geology, 54, $386 \mathrm{p}$.

Berggren, W.A., Pearson, P.N., 2005, A revised tropical to subtropical Paleogene planktonic foraminifera zonation: Journal of Foraminiferal Research, 35(4), 279-298.

Bicchi, E., Ferrero, E., Gonera, M., 2003, Palaeoclimatic interpretation based on Middle Miocene planktonic Foraminifera: the Silesia Basin (Paratethys) and Monferrato (Tethys) records: Paleogeography, Paleoclimatology, Palaeoecology, 196, 265-303.

Bizon, G., Bizon, J.J., 1972, Atlas des principaux Foraminiféres planctoniques du bassin méditerranéen. Oligocéne à Quaternaire: Paris, Editions Techip, IX, 1-316.

Blow, W.H., 1959, Age, correlation and biostratigraphy of the Upper Tocuto (San Lorenzo) and Pozon formations, Eastern Falcón, Venezuela: Bulletin of American Paleontology, 39(178), 59-252.

Blow, W.H., 1969, Late Middle Eocene to Recent Planktonic foraminiferal biostratigraphy: Proceedings of the 1st International Conference on planktonic microfossils: Geneva, 1, 199-422.

Blow, W.H., 1979, The Cenozoic Globigerinidae, A study of the morphology, evolutionary relationships and the stratigraphical distribution of some Globigerinida (mainly Globigerinacea): Leiden, $1-3,1413 \mathrm{p}$

Blow, W.H., Banner, F., 1962, The mid-Tertiary (upper Eocene to Aquitanian) globigerinaceae, in Eames, F.E., Banner, F.T., Blow, W.H., Clarke, W. J. (eds.), Fundamentals of Mid-Tertiary Stratigraphical Correlation: Cambridge, Cambridge University Press, 61-163.

Bolli, H.B., 1957, Planktonic foraminifera from the Oligocene-Miocene Cipero and Lengua formations of Trinidad, B.W.I.: Bulletin of the United States National Museum, 215, 97-123.

Bolli, H.B., Saunders, J.B., Perch-Neilsen, K., 1987, Plankton Stratigraphy: Cambridge Cambridge University Press, 1032 p.

Bozorgnia, F., 1966, Qom Formation stratigraphy of the Central basin of Iran and its intercontinental position: Iranian Petroleum Institute Bulletin, 24, 69-75.

Brady, H.B., 1877, Supplementary note on the foraminifera of the Chalk (?) of The New Britain Group: Geological Magazine, New Series, 4, 534-546.

Brönnimann, P., 1954, Upper Cretaceous Orbitoidal foraminifera from Cuba: Part II: Vaughanina Palmer, 1934: Contributions from the Cushman Foundation for Foraminiferal Research, 5(3), 91-105.

Cushman, J.A. 1921, Foraminifera of the Philippine and adjacent seas: United States National Museum Bulletin, 100, 1-608.

Cushman, J.A., Ellisor, A.O., 1939, New species of foraminifera from the Oligocene and Miocene: Contributions from the Cushman Laboratory for Foraminiferal Research, 15, 1-14.

Daneshian, J., Aftabi, A., 2010, Foraminifera biostratigraphy of the Qom Formation stratigraphic sections based on the new findings, Navab anticline in the South East of Kashan: University of Tehran, Scientific Journal database, 4, 137-154 (in Persian).

Daneshian, J., Ramezani Dana, L., 2007, Early Miocene benthic foraminifera and biostratigraphy of the Qom Formation, Deh Namak, Central Iran: Journal of Asian Earth Sciences, 29, 844-858.

Defrance, M.J.L., 1822, Dictionnaire des Sciences Naturelles: Minéralogie et Géologie, Levrault, Paris, 25, 485p.

d'Orbigny, A., 1826, Tableau méthodique de la classe des Céphalopodes:
Annales Science Naturelle, série 1(7), 245-314.

d'Orbigny, A., 1843, Paléontologie française: Description zoologique et géologique de tous les animaux mollusques \& rayonnés fossiles de France 3: Paris, Arthus Bertrand, $807 \mathrm{p}$

Desmoulins, C., 1837, Troisième mèmoire sur les Échinides. Synonymie généralie: Actes de la Société Linnéenne de Bordeaux, 9(6), 45-364.

Dozy, J.J., 1944, Comments on geological report no. 1 by Thiebaud (on the Qum-Saveh area): Geological Report 308.

Dozy, J.J., 1945, A geological reconnaissance of the area of Veramin and the Siah Kuh (Central Persia): Geological Report 6 (Tehran file).

Dozy, J.J., 1955, A Sketch of past Cretaceous volcanism in Central Iran: Leidsche, Geologische Mededeelingen, 20, 48-57.

Drinia, H., Antonarakou, A., Tsaparas, N., Dermitzakis, M.D., 2007, Foraminiferal stratigraphy and palaeoecological implications in turbidite-like deposits from the Early Tortonian (Late Miocene) of Greece: Journal of Micropaleontology, 26, 145-158.

Drinia, H., Tsaparas, N., Antonarakou, A., 2009, Palaeoenvironmental implications recorded by foraminifera and Bryozoan faunas from the early late Miocene of Gavdos Island: Ninth Symposium on Oceanography \& Fisheries, 85-90.

Drinia, H., Tsaparas, N., Antonarakou, A., Goumas, G., 2003, Benthic foraminiferal associated With Middle to Early Late Miocene oxygen deficient conditions in the Eastern Mediterranean: Eighth International Conference on Environmental Science and Technology, Lemnos Island, Greece, 8-10.

Drinia, H., Koskeridou, H., Antonarakou, A., Tzortzaki, E., 2010, Benthic foraminifera associated with the zooxanthellate coral cladocora in the Pleistocene of the Kos Island (Aegean sea, Greece): Sea level changes and palaeoenvironmental conditions: Bulletin of the Geological Society of Greece, 613-619.

Fuchs, T., 1882, Beitrage zur Kenntniss der Miocean fauna Aegyptens und der libyschen wüste: Palaeontographica, 25, 1-48.

Furon, R., 1941, Geologie du plateau Iranien (Perse-AfghanistanBeloutchistan): Mémoires du Muséum National d'Histoire Naturelle, Nouvelle Serie, Paris, 7(2), 177-414.

Furon, R., Marie, P., 1939, Sur la microfaune des marnes aquitaniennes Lepidocyclines de Qoum (in Persian): Compte Rendu Sommaire des Séances de la Société Géologique de France, 79-80.

Furrer, M.A., Soder, P.A., 1955, The Olige-Miocene marine formation in the Qom region (Central Iran): Proceedings of the $4^{\text {th }}$ World Petroleum Congress, Rome, Section I/A/5, 267-277.

Gansser, A., 1955, New aspects of the geology in Central Iran: Proceedings of the $4^{\text {th }}$ World Petroleum Congress, Rome, Section I/A/5, 279-300.

Gebhardt, H., 1999, Middle to Upper Miocene benthonic foraminiferal palaeoecology of the Tap Marls (Alicante Province, SE Spain) and its palaeoceanographic implications: Palaeogeography, Palaeoclimatology, Palaeoecology, 145, 141-156.

Gibson, T.G., 1989, Planktonic-benthonic foraminiferal ratios: modern patterns and Tertiary applications: Marine Micropalaeontology, $15,29-52$.

Gupa, A.K., Singh, R.K., Verma, S., 2013, Deep-sea palaeoceanographic evolution of the eastern Indian Ocean during the late OligocenePleistocene: species diversity trends in benthic foraminifera: Current Science, 104(7), 1-7.

Hammer, O., Harper, D.A.T., Ryan, P.D., 2001, Paleontological Statistics software package for education and data analysis: Palaeontologia Electronica, 4(1), 9 p.

Hohenegger, J., Rögl, F., Ćorić, S., Pervesler, P., Lirer, F., Roetzel, R., Scholger, R., Stingl,K., 2009, The Styrian Basin: a key to the Middle Miocene (Badenian/Langhian) Central Paratethys transgressions: Austrian Journal of Earth Sciences, 102, 102-132.

Holcová, K., Zágoršek, K., 2008, Bryozoa, foraminifera and calcareous nannoplankton as environmental proxies of the "bryozoan event" in the Middle Miocene of the Central Paratethys (Czech Republic): Palaeogeography, Palaeoclimatology, Palaeoecology, 267(3), 216-234.

Howe, H., Wallace, W.E., 1932, Foraminifera of the Jackson Eocene at Danville landing on the Ouachita, Catahoula parish, Louisiana: Bulletin of the Geological Survey of Louisiana, 2, 18-79. 
Iaccarino, S., 1985, Mediterranean Miocene and Pliocene planktic foraminifera, in Bolli, H.B., Saunders, H. M., Perch-Nielsen, J. B., (eds.), Plankton Stratigraphy, Cambridge, Cambridge University Press, 283-314.

Iaccarino, S., Salvatorini, G., 1982, A framework of planktonic foraminiferal biostratigraphy for Early Miocene to Late Pliocene Mediterranean area: Paleontologia Stratigrafica et Evoluzione, Quaderna, 2, 115-126.

Iaccarino, S.M., Premoli-Silva, I., Biolzi, M., Foresi, M., Lirer, F., Petrizzo, M.R., 2005, Practical Manual of Oligocene to middle Miocene Planktonic Foraminifera: International School on Planktonic Foraminifera 4th course: Università degli Studi di Perugia, Università degli Studi di Parma, Universita degli Studi di Milano, Perugia-Parma- Milano, $124 \mathrm{p}$.

Jalali, M., Feizi, M., 2010, Introduction of Miocene deposits turbidities in the Saveh-Takab area (NW of central Iran basin): The First International Applied Geological Congress, Department of Geology, Islamic Azad University-Mashad Branch, Iran, 26-28.

Kaiho, K., 1994, Benthic foraminiferal dissolved-oxygen index and dissolved-oxygen levels in the modern ocean: Geology, 22, 719-722.

Kaiho, K., 1999, Effect of organic carbon flux and dissolved oxygen on the benthic foraminiferal oxygen index (BFOI): Marine Micropaleontology, 37, 67-76.

Kashfi, M.S., 1988, Evidence for non-collision geology in the Middle East: Journal of Petroleum Geology, 11(4), 443-460.

Khaksar, K., Maghfouri-Moghadam, I., 2007, Paleontological study of the echinoderms in the Qom Formation (Central Iran): Islamic Azad University, Earth Science Research, 11(1), 57-79.

Lamarck, J.B., 1882, Histoire naturelle des animaux sans vertèbres, vol.7. Paris: Srinivasan, M.S., Sharma, V., 1980, Schwagwers car Nicobar Foraminifera in the reports of the Novara Expedition- A revision. New Delhi: Today and Tomorrows Printers and Publishers, 83p.

Le Roy, L.W., 1939, Some small foraminifera, ostracoda and otoliths from the Neogene (Miocene), of the Rokan-Tapanoeli area, Central Sumatra: Natuurkundig Tijdschrift voor Nederlandsch-Indië, 99(6), 215-296.

Lemoine, P., Douvillé, R., 1904, Remarques a propos d' une de M. Prever sur les Orbitoides: Bulletin de la Société Géologique de France, 45, 58-59.

Loeblich, A.R., Tappan, H., 1987a, Foraminiferal genera and their classification: New York, Van Nostrand Reinhold, 970 p.

Loeblich, A.R., Tappan, H., 1987b, Foraminiferal genera and their classification, Plates: New York, Van Nostrand Reinhold, 1059 p.

Mandic, O., Harzhauser, M., 2003, Molluscs from the Badenian (Middle Miocene) of the Gaindorf Formation (Alpine Molasse Basin, NE Austria), Taxonomy, Paleoecology and Biostratigraphy: Annalen des Naturhistorischen Museums in Wien, 104 A, 85-127.

Mandic, O., Harzhauser, M., Spezzaferri, S., Zuschin, M., 2002, The paleoenvironment of an early Middle Miocene Paratethys sequence in NE Austria with special emphasis on mollusks and foraminifera: Geobios, 24, 193-206.

Mohammadi, E., Safari, A., Vaziri-Moghaddam, H., Vaziri, M.R., Ghaedi, M., 2011, Microfacies analysis and paleoenvironmental interpretation of the Qom Formation, South of the Kashan, Central Iran: Carbonates Evaporates, 26, 255-271.

Murray, J.W., 1991, Ecology and Paleoecology of Benthic Foraminifera: London, Longman Scientific \&Technical, 397 p.

Murray, J.W., 2006, Ecology and Applications of Benthic Foraminifera: Cambridge, Cambridge University Press, 422 p.

Murray, J.W., Alve, E., 1999, Natural dissolution of modern shallow water benthic foraminifera: taphonomic effects on the palaeoecological record: Palaeogeography, Palaeoclimatology, Palaeoecology, 146, 195-209.

Nogole-Sadat, M.A.A., 1985, Les zones de Decrochement et lesVirgations structurales en Iran: Consequences des results de 1'analysis structurale de la region de Qom: Geological Survey of Iran, Report 55.

Pezelj, D., Sremac, J., Sokač, A., 2007, Palaeoecology of the Late Badenian foraminifera and ostracoda from the SW Central Paratethys
(Medvednica Mt., Croatia): Geologia Croatica, 60(2), 139-150.

Pezelj, D., Mandic, O., Ćorić, S., 2012, Paleoenvironmental dynamics in the southern Pannonian Basin during initial Middle Miocene marine flooding: Geologica Carpathica, 64(1), 81-100.

Pippèrr, M., 2011, Characterization of Ottnangian (middle Burdigalian) palaeoenvironments in the North Alpine Foreland Basin using benthic foraminifera - A review of the Upper Marine Molasse of southern Germany: Marine Micropaleontology, 79, 80-99.

Pippèrr, M., Reichenbacher, B., 2010, Foraminifera from the borehole Altdorf (SE Germany): Proxies for Ottnangian (early Miocene) palaeoenvironments of the Central Paratethys: Palaeogeography, Palaeoclimatology, Palaeoecology, 289, 62-80.

Pomel, A., 1887, Paléontologie ou description des animaux fossils de l'Algérie. Zoophytes. 2e fascicule Échinodermes, 2e Livraison: Alger, Adolphe Jourdan, 344 p.

Popov, S.V., Rögl, F., Rozanov, A.Y., Steininger, F.F., Shcherba, I.G., Kovac, M., 2004, Lithological-paleogeographic maps of Paratethys. 10 maps Late Eocene to Pliocene: Courier Forschungsinstitut Senckenberg, 250, 1-46.

Poroohan, N., Teimoornegad, K., Mohajjel, M., 2009, Geometry and Kinematics of Qom-Zefreh Fault System and its Significance in Transpresssion Tectonics: Proceedings of the Third IASME/WSEAS International Conference on Geology and Seismology, 53-57.

Postuma, J.A., 1971, Manual of Planktonic Foraminifera: Amsterdam, Elsevier, $420 \mathrm{p}$.

Rahaghi, A., 1980, Tertiary faunal Assemblage of Qum-Kashan, Sabzewar and Jahrum area: National Iranian Oil Company, Geological Laboratories, Publication 8.

Rai, A.K., Maurya, A.S., 2009, Effect of Miocene paleoceanographic changes on the benthic foraminiferal diversity at ODP site 754A (Southeastern Indian Ocean): Indian Journal of Marine Sciences, 38(4), 423-431.

Reuss, A.E., 1850, Neues Foraminiferen aus den Schichten des Österreichisch Teriärbeckens, Denkschriften der Kaiserlichen Akademie der Wissenschaften: Mathematisch-Naturwissenschaftliche classe, 1, 365-390

Reuter, M., Pillar, W.E., Harzhauser, M., Mandic, O., Berning, B., Rögl, F., Kroh, A., Aubry, M.P., Wielandt Schuster, U., Hamedani, A., 2009, The Oligo-Miocene Qom Formation (Iran): Evidence for an early Burdigalian restriction of Tethyan Seaway and closure of its Iranian gateways: International Journal of Earth Sciences, 98, 627-650.

Rögl, F., 1969, Die Foraminiferen fauna aus den Phosphorit sanden von Plesching bei Linz (Oberösterreich) Ottnangien (Untermiozän): Naturkundliches Jahrbuch der Stadt Linz, 213-234.

Rögl, F., 1998, Palaeogeographic considerations for Mediterranean and Paratethys seaways (Oligocene to Miocene): Annalen des Naturhistorischen Museums in Wien, 99(A), 279-310.

Rögl, F., Spezzaferri, S., 2003, Foraminiferal paleoecology and biostratigraphy of the Mühlbach section (Gaindorf Formation, Lower Badenian), Lower Austria: Annalen des Naturhistorischen Museums in Wien, 104(A), 23-75.

Sacco, F., 1897, I molluschi dei terreni terziari dei Piedmonte e della Liguria: Memorie Royal Accademie Science Torino, 3-24.

Schuster, F., Wielandt, U., 1999, Oligo-miocene and Early Miocene coral faunas from Iran: Palaecology and palaeobiogeography: International Journal of Earth Sciences, 88, 571-581.

Sen-Gupta, B.K., Machain-Castillo, M.L., 1993, Benthic foraminifera in oxygen-poor habitats: Marine Micropaleontology, 20, 183-201.

Seyrafian, A., Torabi, H., 2005, Petrofacies and sequence stratigraphy of the Qom Formation (Late Oligocene-Early Miocene?), north of Nain, southern trend of Central Iranian Basin: Carbonates and Evaporates, 20(1), 82-90.

Sgarrella, F., Moncharmont Zei, M., 1993, Benthic foraminifera of the Gulf of Naples (Italy): Systematics and autoecology: Bollettino della Società Palaeontologica Italiana, 32(2), 145-264.

Sismonda, E., 1842, Appendice alla monografia degli Echinidi Fossili del Piemonte: Memoria della Reale Accademia della Scienze di Torino, 2(4), 385-394. 
Spezzaferri, S., 1995, Planktonic foraminiferal paleoclimatic implications across the Oligocene-Miocene transition in the oceanic record (Atlantic, Indian and South Pacific): Palaeogeography, Palaeoclimatology, Palaeoecology, 114, 43-74.

Spezzaferri,S., Ćorić, S., Hohenegger, J., Rögl, F., 2002, Basin-scale paleobiogeography and Paleoecology: an example from Karpatian (Latest Burdigalian) benthic and planktonic foraminifera and calcareous nannofossils from the Central Paratethys: Geobios, Mémoire spécial, 24, 241-256.

Stainforth, R.M., Lamb, J.L., Luterbacher, H., Beard, J.H., Jeffords, R.M., 1975, Cenozoic planktonic foraminiferal zonation and characteristics of index forms: The University of Kansas Paleontological Contributions, 62, 1-425.

Stassen, P., Dupuis, C., Morsi, A.M.M., Steurbaut, E., Speijer, R.P., 2009, Reconstruction of a latest Paleocene shallow-marine eutrophic paleoenvironment at Sidi Nasseur (Central Tunisia) based on foraminifera, ostracoda, calcareous nannofossils and stable isotopes $\left(\delta^{13} \mathrm{C}, \delta^{18} \mathrm{O}\right)$ : Geologica Acta, 7(1-2), 93-112.

Stefanelli, S., 2003, Benthic foraminiferal assemblages as tools for paleoenvironmental reconstruction of the Early-Middle Pleistocene Montalbano Jonico composite section: Bollettino della Società Paleontologica Italiana, 42 (3), 281-299.

Stefanelli, S., 2004, Cyclic changes in oxygenation based on foraminifera microhabitats: Early-Middle Pleistocene, Lucania Basin (southern Italy): Journal of Micropaleontology, 23, 81-95.

Stöcklin, J., Setudehina, A., 1991, Stratigraphic lexicon of Iran: Geological Survey of Iran, Tehran, Republic 18, Third edition, $376 \mathrm{p}$

Tyszka, J., 2001, Microfossil assemblages as bathymetric indicators of the Toarcian-Aalenian "Fleckenmergel"-facies in the Carpathian Pieniny Klippen belt: Geologica Carpathica, 52(3), 147-158.
Van Der Zwaan, G.J., Jorissen F.J., De Stigter, H.C., 1990, The depth dependency of planktonic/benthic foraminiferal ratios: Constrains and applications: Marine Geology, 95, 1-16.

Wilson, B., 2003, Foraminifera and Paleodepths in a section of the Early to Middle Miocene Brasso Formation, Central Trinidad: Caribbean Journal of Science, 39(2), 209-214.

Yazdi, M., Parvanenejad Shirazi, M., Rahiminejad, A.H., Motavalipoor, R., 2012, Paleobathymetry and paleoecology of colonial corals from the Oligocene-early Miocene(?) Qom Formation (Dizlu area, central Iran): Carbonates and Evaporates, 6, 395-405.

Zágoršek, K., Holcová, K., Nehyba, S., Kroh, A., Hladilova, Š., 2009, The invertebrate fauna of the Middle Miocene (Lower Badenian) sediments of Kralice and Oslavou (Central Paratethys, Moravian part of the Carpathian Foredeep): Bulletin of the Geosciences, 84(3), 465-496.

Zahedi, M., Amidi, M., 1978, Geologic map of the Isfahan: Geological Survey of Iran, scale 1/250000.

Zhu, Y., Qi, Y., Zhang, B., Yang, H., He, C., Wang, S., Zhou, W., Zhu, Q., Li, Z., 2007, Revision of the age of the Qom Formation in the Central Iran Basin, Iran: Journal of Asian Earth Sciences, 29, 715-721.

Manuscript received: June 23, 2014.

Corrected manuscript received: November 25, 2014.

Manuscript accepted: December 7, 2014. 